\title{
Beth Driscoll and Claire Squires: The Frankfurt Book Fair and Bestseller Business
}

\section{Cambridge University Press, Cambridge, United Kingdom, 2021, 112 pp., \$ 12.35, Paperback, ISBN 978-1-108-92810-6}

\section{Robert E. Baensch ${ }^{1}$}

Published online: 20 October 2021

(c) The Author(s), under exclusive licence to Springer Science+Business Media, LLC, part of Springer Nature 2021

Here is a very different or non-traditional approach to providing background information and a guide for the Frankfurt Book Fair when it was still the largest international book event before the Covid-19 Pandemic forced it and many other international events into a new digital and online events. The report is based on the authors' experiences, fieldwork and research visiting the Book Fair in 2017, 2018 and 2019. My emphasis on a different approach is because we encounter "buzz", experiences linked to mood, elements of pseudo (neo) liberal self-satisfaction of book culture and the concept of Ullapoolism. To confirm this new and different approach, the four chapters are: 1. Introduction, 2. Book Buzz, 3. Big, small, Nowhere at All, 4. Carnivalesque and 5. Conclusion: the Broom of History.

The introduction provides "Flight Paths" for paper planes which according to the authors are "fun to make and fun to fly" and provide descriptive flights for the history and description of the largest book fair in the world. It is also here that the authors introduce the Ullapoolist research approach as a "programme of playful, material, satirical and sociable research producing situated knowledge and creative critique and using arts-informed methods." The authors devote considerable text on how their methods use Ullapoolism to go to the Book Fair. Namely, they provide a list of fourteen methods including Fortune Telling Mood Fish, Penny Power and Polly Pringle Journalism, the Sleaze-O-Meter, Non-actualized Methods and conclude with a "Guess Who Am I?".

The authors present a very good review of the event, participation and background literature to place the Frankfurt Book Fair pre Covid-19 into proper perspective.

Chapter 2 introduces the concept of "Book Buzz" by describing the immediate discussions, digital information, print distribution of information before, during and

Robert E. Baensch

BaenschRE@gmail.com

$1 \quad$ Frankfurt am Main, Germany 
after the Frankfurt Book Fair. There is chart that presents a five point "Mood Scale" for the fair and a complex diagram to display the multiple fields of buzz production.

Chapter 3 starts with the strong recommendations to "wear comfortable shoes" and moves on with an analysis of the halls, exhibit spaces, location of power centers and overall structure of the halls for an event that hosts 7450 publishers exhibits from 114 countries. This chapter covers from the overview of the exhibit areas down to an analysis of the actual booth size, strategic locations as well as a look behind the exhibits. There is a detailed description of the authors' construction of to the cardboard of models of exhibit spaces including a doll house size version of the Hachette stand. Considerable text is devoted to the Cardboard Buchmesse including review for grouping of exhibits, various custom size exhibits, and other "dynamics" of the exhibit halls.

Chapter 4 examines the Fair as a "carnivalesque": event-what all events and entertainment are made available by publishers from monographing services to the many different forms reviewed by the authors. They describe their experiences as participant observers of the multitude of social events as Stand Parties and evening events. There is an interesting discussion of national groupings, stereotypes and racism as key factors of the Buchmesse and their role in the largest global event for book publishers open to all countries.

Chapter 5 presents a conclusion or "Broom History" which describes an interesting Ullapoolist adaptation of the game "Guess Who" to actively evaluate the personal interactions including networking, meetings, event participation. The goal is to produce positive results for the international movement (export sales and rights sales) of books. The conclusion of "The Pseudo (Neo) liberal Self-Satisfaction of Book Culture" brings this very different discussion and description of the Frankfurt Book Fair to closure.

I only regret that the Editors of Cambridge University Press did not invite an author or authors to write a review of the Scientific, Technical, Medical and Digital sector of the Frankfurt Book Fair to provide a part 2 for a more complete review of the largest book event in the world.

Publisher's Note Springer Nature remains neutral with regard to jurisdictional claims in published maps and institutional affiliations. 